\title{
The expression of the Acinetobacter calcoaceticus recA gene increases in response to DNA damage independently of RecA and of development of competence for natural transformation
}

\author{
Peter J. G. Rauch, ${ }^{1} \dagger$ Ronald Palmen, ${ }^{1} \ddagger$ Aurora A. Burds, ${ }^{2}$ \\ Leslie A. Gregg-Jolly, ${ }^{2}$ J. Rob van der Zee ${ }^{1}$ and Klaas J. Hellingwerf ${ }^{1}$ \\ Author for correspondence: Klaas J. Hellingwerf. Tel: +3120 5257055. Fax: +31205257056. \\ e-mail: A417hell@horus.sara.nl
}

1 Department of Microbiology, E. C. Slater Institute, BioCentrum Amsterdam, Nieuwe Achtergracht 127, $1018 \mathrm{TV}$ Amsterdam, The Netherlands

2 Department of Biology, Grinell College, Grinell, IA 50112, USA

\begin{abstract}
Using the lacz operon fusion technique, the transcriptional control of the Acinetobacter calcoaceticus recA gene was studied. A low (approximately twofold) inductive capacity was observed for compounds that damage DNA and/or inhibit DNA replication, e.g. methyl methanesulfonate, mitomycin C, UV light and nalidixic acid. Induction of the recA gene by DNA damage was independent of functional RecA. The presence of the recA promoter region on a multicopy plasmid had the same effect on recA transcription as the presence of DNA-damaging agents. Thus, recA expression in A. calcoaceticus appears to be regulated in a novel fashion, possibly involving a non-LexA-like repressor. Regulation of the recA gene in A. calcoaceticus appears not to be part of a regulon responsible for competence for natural transformation: in cells exhibiting extremely low transformation frequencies, the level of transcription of the recA gene was found to be comparable to the level found in cells in the state of maximal competence.
\end{abstract}

Keywords: Acinetobacter calcoaceticus, $\operatorname{rec} A$ gene, DNA damage, natural transformation, competence

\section{INTRODUCTION}

RecA is the major enzyme involved in homologous recombination (Cox, 1991). The $\operatorname{rec} A$ gene from approximately 35 different organisms has been cloned and completely or partially sequenced (for a review, see Miller \& Kokjohn, 1990). Among these are nine naturally transformable organisms: the Gram-negative organisms Acinetobacter calcoaceticus (Gregg-Jolly \& Ornston, 1994), Azotobacter vinelandii (Venkatesh \& Das, 1992), Campylobacter jejuni (Guerry et al., 1994), Haemopbilus infuenzae (Zulty \& Barcak, 1993), Neisseria gonorrboeae (Story et al., 1993), Pseudomonas stutzeri (Vosman et al., 1993) and

\footnotetext{
†Present address: Division of Industrial Microbiology, Wageningen Agricultural University, Department of Food Science, Bomenweg 2, 6703 HD Wageningen, The Netherlands.

¥Present address: CHU Rangueil, Laboratoire de Bactériologie-VirologieHygiène (Bat L1), Av. Jean Poulhs, 31054 Toulouse Cedex, France.

Abbreviations: MMS, methyl methanesulfonate; MU, Miller units; ssDNA, single-stranded DNA.
}

Thiobacillus ferrooxidans (Ramesar et al., 1989) and the Gram-positive bacteria Streptococcus pneumoniae (Dybvig et al., 1992; Martin et al., 1992) and Bacillus subtilis (Stranathan et al., 1990). In Escherichia coli, rec $A$ expression is induced by the presence of single-stranded DNA (ssDNA) resulting, for instance, from DNA damage (Higashitani et al., 1992). In short, the RecA protein binds to ssDNA, forming a nucleoprotein filament (Story et al., 1993). The filament enhances the autoprotease activity of LexA. Cleaved LexA subsequently derepresses a large number of genes involved in repair of DNA damage, the so-called SOS response genes, including $\operatorname{rec} A$ and $\operatorname{lex} A$ (Little \& Mount, 1982).

In natural transformation, incoming homologous chromosomal DNA has to become incorporated into the recipient's chromosome before genetic determinants, present on this DNA, can be expressed. Therefore, natural transformation is also dependent on homologous recombination. The importance of $\operatorname{Rec} A$ in natural transformation is underlined by the observation that expression of the $\operatorname{rec} A$ gene of $B$. subtilis, $S$. pneumoniae and 
Streptococcus sanguis (all Gram-positive bacteria) is induced upon induction of competence (Wise et al., 1973; De Vos \& Venema, 1982; Raina \& Macrina, 1982). The $\operatorname{rec} A$ gene of both $B$. subtilis and $S$. pneumoniae is subject to dual regulation (Cheo et al., 1991, 1993; Raymond-Denise \& Guillen, 1992; Pearce et al., 1995; Martin et al., 1995). In these organisms, transcription of $\operatorname{rec} A$ is regulated both by an SOS response [dependent on functional RecA (RecE) and Lex A (DinR)] and by the regulatory pathway that controls competence development for natural transformation (independent of functional RecA).

With respect to the naturally transformable Gramnegative bacteria, much less is known about the regulation of $\operatorname{rec} A$ transcription in relation to induction of competence. This paper describes an analysis of $A$. calcoaceticus $\operatorname{rec} A$ transcriptional regulation using the lac $Z$ operon fusion technique. Induction of $\operatorname{rec} A$ transcription was studied in particular in response to (i) DNA damage, (ii) development of competence for natural transformation and (iii) the presence of functional RecA.

\section{METHODS}

Bacteria, plasmids and growth conditions. Strains and plasmids used in this study are listed in Table 1. Plasmid pAKA1024-32 is based on the E. coli vector pUN121 (Nilsson et al., 1983) and contains a $3.5 \mathrm{~kb}$ EcoRI fragment with the chloramphenicol-resistance gene from pK'T210 (Bagdasarian $e t$ al., 1981), flanked by two $2 \cdot 1 \mathrm{~kb}$ regions from the $A$. calcoaceticus BD413 chromosome. In this construct, the $3.5 \mathrm{~kb}$ EcoRI fragment replaces a $4.3 \mathrm{~kb}$ region of the $A$. calcoaceticus BD 413 chromosome, containing the est $A$ gene (Kok et al., 1993). The chloramphenicol-resistance gene is efficiently inserted into the A. calcoaceticus BD413 chromosome via homologous recombination in these flanking regions. Plasmid pARA0 is based on pUN121 and contains a chromosomal $2.4 \mathrm{~kb}$ HindIII fragment with the $A$. calcoaceticus BD413 rec $A$ gene. Plasmid pAVP21 contains the promoterless E. coli lac $Z$ gene from pJO220, followed by the nptII gene (encoding kanamycin resistance) from pUC4K (Vieira \& Messing, 1982). Plasmid pWH1274 is an E. coli-A. calcoaceticus shuttle vector (Hunger et al., 1990).

E. coli strains were grown in Luria-Bertani (LB) medium (Sambrook et al., 1989). A. calcoaceticus was grown in batch cultures in $\mathrm{LB}$ medium or in minimal medium at $30^{\circ} \mathrm{C}$ with aeration in a rotary shaker. Acinetobacter minimal medium and minimal agar were prepared according to Juni (1974). They contained $60 \mathrm{mM}$ lactic acid, $11 \mathrm{mM} \mathrm{KH}_{2} \mathrm{PO}_{4}, 95 \mathrm{mM}$ $\mathrm{Na}_{2} \mathrm{HPO}_{4}, 0.81 \mathrm{mM} \mathrm{MgSO}, 37 \mathrm{mM} \mathrm{NH}_{4} \mathrm{Cl}, 0.068 \mathrm{mM} \mathrm{CaCl}_{2}$, $1.8 \mu \mathrm{M} \mathrm{FeSO}$ and $1.5 \%(\mathrm{w} / \mathrm{v})$ agar for the latter. The $A$. calcoaceticus chemostat medium consisted of minimal medium (Juni, 1974) with Vishniac trace element solution $\left(1 \mathrm{ml} \mathrm{l}^{-1}\right)$ and $15 \mu \mathrm{g}$ kanamycin $\mathrm{ml}^{-1}$. One litre of Vishniac trace element solution contained: $1 \mathrm{~g} \mathrm{Na}$-EDTA, $2.5 \mathrm{~g} \mathrm{FeSO}_{4} .7 \mathrm{H}_{2} \mathrm{O}, 0.2 \mathrm{~g}$ $\mathrm{ZnSO}_{4} .7 \mathrm{H}_{2} 0,0.5 \mathrm{~g} \mathrm{MnCl}_{2} .4 \mathrm{H}_{2} \mathrm{O}, 50 \mathrm{mg} \mathrm{H}_{3} \mathrm{BO}_{4}, 150 \mathrm{mg}$ $\mathrm{CoCl}_{2} \cdot 6 \mathrm{H}_{2} \mathrm{O}, 150 \mathrm{mg} \mathrm{CuCl}_{2} \cdot 5 \mathrm{H}_{2} \mathrm{O}, 25 \mathrm{mg} \mathrm{NiCl} \cdot 6 \mathrm{H}_{2} \mathrm{O}$, $100 \mathrm{mg}\left(\mathrm{NH}_{4}\right)_{6} \mathrm{Mo}_{7} \mathrm{O}_{24} \cdot 4 \mathrm{H}_{2} \mathrm{O}$ and $50 \mathrm{mg} \mathrm{Na} \mathrm{WO}_{4} \cdot 2 \mathrm{H}_{2} \mathrm{O}$. The chemostat experiments were performed in a Bioflo model C30 fermenter (New Brunswick Scientific) at $30^{\circ} \mathrm{C}$. The $\mathrm{pH}$ was regulated at $7 \cdot 0$ by titration with $1 \mathrm{M} \mathrm{HCl}$. The working volume of the culture vessel was $340 \mathrm{ml}$. The cultures were aerated with a flow of 1.21 air $\mathrm{min}^{-1}$, with a stirring rate of 400 r.p.m.

When appropriate, media were supplemented with antibiotics in the following amounts (unless stated otherwise): ampicillin, $100 \mu \mathrm{g} \mathrm{ml}^{-1}$ (E. coli) or $200 \mu \mathrm{g} \mathrm{ml}^{-1}$ (A. calcoaceticus); chloramphenicol, $50 \mu \mathrm{g} \mathrm{ml}^{-1}$ (A. calcoaceticus); kanamycin, $50 \mu \mathrm{g} \mathrm{m} \mathrm{m}^{-1}$ (E. coli) or $15 \mu \mathrm{g} \mathrm{ml}^{-1}$ (A. calcoaceticus).

A. calcoaceticus transformations. $A$. calcoaceticus strains were grown to competence as follows: an overnight culture in LB medium was diluted $1: 25$ in fresh LB medium and cultured for an additional $2 \mathrm{~h}$ at $30^{\circ} \mathrm{C}$. At this stage, the culture is competent for genetic transformation. When transformation frequencies of cultures were to be determined (as a measure of the level of competence for natural transformation), the transformation protocol used was as follows. A culture $(0.5 \mathrm{ml})$ was incubated for $60 \mathrm{~min}$ with $2 \mu \mathrm{g}$ pAKA1024-32. Subsequently, $50 \mu \mathrm{g}$ DNase I was added to terminate further DNA uptake and the transformation mixture was incubated for an additional $90 \mathrm{~min}$ to allow expression of the transformed chloramphenicol-

Table 1. Strains and plasmids used in this study

\begin{tabular}{|c|c|c|}
\hline Strain/plasmid & Relevant geno/phenotype* & Reference \\
\hline \multicolumn{3}{|l|}{ Strains } \\
\hline A. calcoaceticus BD413 & Wild-type & Juni (1972) \\
\hline A. calcoaceticus AAC406 & $\operatorname{rec} A:: \operatorname{lac} Z:: n p t I I$ & This study \\
\hline A. calcoaceticus AAC407 & $\operatorname{rec} A^{+} \operatorname{rec} A:: \operatorname{lac} Z:: n p t I I$ & This study \\
\hline E. coli $\mathrm{DH} 5 \alpha$ & $\operatorname{rec} A 1$ & Hanahan (1983) \\
\hline E. coli AB1157 & $\operatorname{rec} A^{+}$ & $\begin{array}{l}\text { B. J. Bachmann, Yale } \\
\text { University, CT, USA }\end{array}$ \\
\hline \multicolumn{3}{|l|}{ Plasmids } \\
\hline pAKA1024-32 & $\mathrm{Cm}^{\mathrm{r}}$ & Kok et al. (1993) \\
\hline pAVP21 & lacZ::nptII & Vosman et al. (1993) \\
\hline pARA0 & $\mathrm{Amp}^{\mathrm{r}} \operatorname{rec} A^{+}$ & Palmen et al. (1992) \\
\hline pARA4 & $\operatorname{Amp}^{\mathrm{r}} \operatorname{rec} A:: \operatorname{lac} Z:: n p t I I$ & This study \\
\hline pARA11 & $A m p^{r}$ & This study \\
\hline pWH1274 & $A m p^{r}$ & Hunger et al. (1990) \\
\hline
\end{tabular}

* Ampr and $\mathrm{Cm}^{\mathrm{r}}$ refer to resistance to ampicillin and chloramphenicol, respectively. 
(a) Replacement recombination:

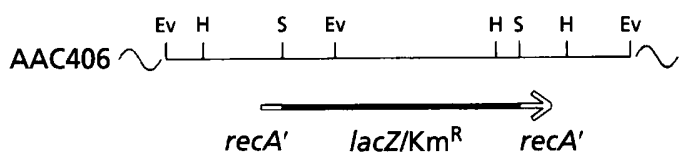

(b) Campbell-like integration:

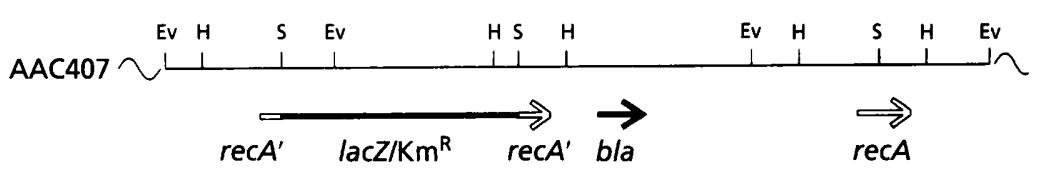

$1 \mathrm{~kb}$

(c)

Inserts:
Fig. 1. Restriction maps of the chromosomal recA region of the recombinant $A$. calcoaceticus strains AAC406 (a) and AAC407 (b) and of the chromosomal inserts in PARA4 and PARA11 (c). Ev, ECORV; H, HindIII; S, Sall. resistance marker. In all other transformations (carried out with several different plasmid-DNA samples), the incubation time with DNA was extended to $3 \mathrm{~h}$ and no DNase I was added. Transformants were selected on LB plates containing the appropriate antibiotic(s).

DNA techniques. Chromosomal DNA was isolated from $A$. calcoaceticus as described by Vosman \& Hellingwerf (1991). Plasmid DNA was purified from $A$. calcoaceticus using lysis by boiling (Sambrook et al., 1989). All additional molecular genetic techniques were carried out according to standard protocols (Sambrook et al., 1989). In the cloning procedures, enzymes and reagents were used as recommended by the manufacturer (Pharmacia LKB Biotechnology AB).

Construction of the recA: : lacZ fusion strains. The unique $S a l I$ restriction site in the $\operatorname{rec} A$ gene (Palmen et al., 1992; GreggJolly \& Ornston, 1994) in pARA0 was used to insert the lacZ::nptII cassette from pAVP21 as a $4.5 \mathrm{~kb}$ SalI fragment. This resulted in plasmid pARA4 (see also Fig. 1c). It has been shown that insertion of an nptII gene in this site in the chromosome of $A$. calcoaceticus leads to a RecA-deficient phenotype (Palmen et al., 1992). As expected, E. coli DH $5 \alpha$, containing pARA4, was sensitive to the addition of $0.03 \%$ methyl methanesulfonate (MMS) and resistant to kanamycin. Furthermore, this strain showed high-level expression of $\beta$ galactosidase, in contrast to E. coli(pARA3). The plasmid in this latter strain is identical to pARA4, except that it contains the $4.5 \mathrm{~kb} \mathrm{SalI}$ fragment, bearing lacZ::nptII, in the opposite orientation. Restriction analyses, based on nucleotide sequence information (Gregg-Jolly \& Ornston, 1994), confirmed that pARA4 has the lac $Z$ gene under control of the $\operatorname{rec} A$ promoter.

To construct chromosomal $\operatorname{rec} A:$ : lac $Z$ fusion strains, pARA4 was introduced into $A$. calcoaceticus $\mathrm{BD} 413$ via natural transformation. Plasmids based on pUN121 do not replicate in $A$. calcoaceticus. Kanamycin-resistant, $\beta$-galactosidase-producing transformants can only be formed by integration of the lac $Z$ :: nptII cassette via homologous recombination, facilitated by the $\operatorname{rec} A$ sequences, into the host chromosome. Basically, integration can occur via two recombination events: (i) via replacement recombination, resulting from homologous recombination on both flanking sequences of the lac $Z:$ :nptII cassette, or (ii) via a Campbell-like mode of insertion, resulting from a single recombination event on one of the two flanking sequences. In the case of a Campbell-like integration, the entire plasmid will be integrated, whereas replacement recombination results in insertion of the lacZ::nptII cassette only and in disruption of $\operatorname{rec} A$. Replacement recombinants will therefore be kanamycin-resistant and RecA-deficient. After transformation of BD413 with pARA4, strains with a kanamycin-resistant phenotype were selected and screened for sensitivity towards MMS and ampicillin. Restriction analysis combined with Southern hybridization showed that the organization of the $\operatorname{rec} A$ region was as expected (Fig. 1a). Two strains were initially selected for further use (AAC406/1 and AAC406/2).

Campbell-like integration (also termed duplication insertion) results in duplication of the homologous DNA fragment on the plasmid taking part in the insertional recombination reaction. Plasmid pARA4 contains two homologous fragments, of 1.5 and $0.9 \mathrm{~kb}$, flanking the inserted lac $Z:: n p t I I$ cassette. Therefore, two types of transformants were expected. One type would result from recombination on the $1.5 \mathrm{~kb}$ homologous fragment and would possess the chromosomal gene arrangement depicted for AAC407 in Fig. 1(b). Recombination on the $0.9 \mathrm{~kb}$ homologous fragment of pARA4 would result in a reverse gene arrangement, i.e. the wild-type $\operatorname{rec} A$ gene would precede the $\operatorname{rec} A$ : : lac $Z$ fusion. Transformants having pARA4 integrated according to a Campbell-like mechanism will be kanamycin-and ampicillin-resistant, and RecA-proficient. After transformation of BD413 with pARA4, transformants resistant to MMS, kanamycin and ampicillin were selected. Restriction analysis combined with Southern hybridization of three of these transformants confirmed that in all three of them, the chromosomal $\operatorname{rec} A$ region is as shown in Fig. 1(b). For this study, this is also the preferred arrangement because all possible regulatory signals upstream of the $\operatorname{rec} A$ ::lac $Z$ promoter are conserved. Also, for the Campbell-like integration, two strains were initially used for further study (AAC407/1 and AAC407/2). However, both the AAC406 and the AAC407 set of strains did not produce significantly different data sets. Therefore, no distinction will be made between the two isogenic strains. Their data sets have been combined and the four strains will be referred to as AAC406 and AAC407, respectively, below.

Construction of the recA promoter plasmid. A plasmid that was able to replicate in $A$. calcoaceticus and that contained the 
promoter region of the $A$. calcoaceticus rec $A$ gene, pARA11, was constructed by ligating the $1.5 \mathrm{~kb}$ HindIII-Sall fragment from pARA0 (Palmen et al., 1992; Fig. 1c) into pWH1274 (Hunger et al., 1990). The $1.5 \mathrm{~kb}$ fragment contains $0.4 \mathrm{~kb}$ of the $5^{\prime}$-end of the $\operatorname{rec} A$ gene and $1.1 \mathrm{~kb}$ of upstream sequence.

Measurement of recA::lacZ transcription levels. $\beta$ Galactosidase levels were determined according to Miller (1982) and are expressed in Miller units (MU). Levels of $\beta$-galactosidase presented are always the mean of duplicate measurements.

The effects of different DNA-damaging agents on $\operatorname{rec} A$ transcription were determined as follows. An overnight culture of a $\operatorname{rec} A$ : : lac $Z$ operon fusion strain in LB medium, containing the appropriate antibiotic(s), was diluted $1: 25$ into fresh medium. After $2 \mathrm{~h}$ growth at $30^{\circ} \mathrm{C}$, a DNA-damaging agent was added to the culture, which was incubated for an additional $2 \mathrm{~h}$ before samples for the $\beta$-galactosidase activity measurements were taken. UV irradiation ( $254 \mathrm{~nm}$ ) was carried out on $6 \mathrm{ml}$ samples of a culture in open Petri dishes $(9 \mathrm{~cm}$ diameter).

Protein concentrations were determined according to Bradford (1976) using Bradford reagent from Bio-Rad.

The $\mathrm{OD}_{540}$ was measured with a Beckman DU-40 spectrophotometer.

\section{RESULTS}

\section{Construction of recA:: lacZ operon fusion strains}

To study the regulation of transcription of the $\operatorname{rec} A$ gene via detection of $\beta$-galactosidase activity, two strains were constructed in which lac $Z$ expression is controlled by the $\operatorname{rec} A$ promoter. One of these strains, AAC406, exhibits a $\operatorname{Rec} \mathrm{A}^{-}$phenotype, due to distuption of the $\operatorname{rec} A$ gene by the lac $Z$ insertion (Fig. 1a). The other strain, AAC407, carries a wild-type copy of $\operatorname{rec} A$ downstream of the operon fusion (Fig. 1b) and therefore exhibits a $\operatorname{Rec} \mathrm{A}^{+}$ phenotype. In batch cultures of both types of strains, significant $\beta$-galactosidase levels were found (see below), while cultures of strains containing the lac $Z$ gene in the opposite orientation with respect to the $\operatorname{rec} A$ gene showed low $\beta$-galactosidase levels, comparable to the level found in the wild-type strain BD413 (data not shown).

AAC407 was constructed via a Campbell-like insertion (also termed duplication insertion) of plasmid pARA4. This type of integration results in duplication of the homologous DNA fragment on the plasmid taking part in the insertional recombination reaction. In Deinococcus radiodurans and $H$. influenzae, Campbell-like insertion easily leads to amplification of the inserted fragment (Masters $e t$ al., 1991; Zulty \& Barcak, 1993). Ten or more copies of the inserted fragment can often be detected on the chromosome. Therefore, chromosomal DNA of strain AAC407, besides being checked for integration, was also checked for amplification of the inserted fragment by Southern hybridization of EcoRV-digested chromosomal DNA, with the $2.3 \mathrm{~kb}$ HindIII fragment from pARA0 containing the entire $\operatorname{rec} A$ gene as a probe. EcoRV restriction results in the formation of a fragment containing the wild-type $\operatorname{rec} A$ gene, a second fragment containing the first part of the $\operatorname{rec} A:: \operatorname{lac} Z$ fusion and a third fragment containing the second part of the $\operatorname{rec} A$ : : lac $Z$ fusion. In the case of amplification, only the copy number of the latter fragment would increase. This increase can be visualized via hybridization with the $\operatorname{rec} A$ gene, by comparing the colour intensity of the hybridizing signals of the three fragments. The Southern blot clearly revealed that pARA4 had been integrated into the $A$. calcoaceticus chromosome. No indication, however, was found of a possible amplification of the inserted fragment in strain AAC407.

\section{Induction of recA transcription by DNA-damaging agents}

The effect of DNA damage on transcription of $\operatorname{rec} A$, determined via the $\beta$-galactosidase levels in the $\operatorname{rec} A:: \operatorname{lac} Z$ fusion strains, was tested. In $E$. coli, and in all other bacteria in which this was tested, SOS induction was dependent on the presence of a functional RecA protein (Little \& Mount, 1982; Lovett et al., 1988; Venkatesh \& Das, 1992; Vosman et al., 1993; Zulty \& Barcak, 1993). Surprisingly, this is not the case in $A$. calcoaceticus: $2 \mathrm{~h}$ after the addition of $4 \mu \mathrm{g}$ mitomycin $\mathrm{C} \mathrm{ml}^{-1}, \operatorname{rec} A$ gene transcription was induced approximately twofold, both in AAC406 [no functional RecA; induced 2.3-fold from 980 $\mathrm{SD} \pm 100$ to $2250 \pm 110 \mathrm{MU}$ (mean of eight independent experiments)] and in AAC407 [RecA-proficient; induced 1.8-fold from $740 \pm 70$ to $1350 \pm 90 \mathrm{MU}$ (mean of eight independent experiments)]. Similar results were obtained with $8 \mu \mathrm{g}$ mitomycin $\mathrm{C} \mathrm{m}{ }^{-1}, 20 \mu \mathrm{g}$ nalidixic acid $\mathrm{ml}^{-1}$, $0.04 \%$ MMS and with UV light $\left(254 \mathrm{~nm}, 20 \mathrm{~J} \mathrm{~m}^{-2}\right)$ as the damage-inducing agent (data not shown).

When the $\beta$-galactosidase level of cultures of strains AAC406 and AAC407 was followed with time during growth in batch culture (Fig. 2), it could be seen that both strains displayed a basic level of $\operatorname{rec} A$ expression. After the addition of mitomycin $\mathrm{C}$ (which also negatively affected the growth of both strains), the $\beta$-galactosidase level increased approximately twofold in $2-3 \mathrm{~h}$ in both strains. Thus, while $A$. calcoaceticus $\operatorname{rec} A$ expression exhibited a time-course of DNA-damage induction that was comparable to that found in other organisms, it was unique in the respect that it was independent of functional RecA.

The fact that induction of $\operatorname{rec} A$ gene transcription after DNA damage was independent of the presence of functional RecA protein indicates that the expression of $A$. calcoaceticus $\operatorname{rec} A$ is regulated in a novel, non-SOS-like fashion. In order to determine if an activator or a repressor is involved in the regulation of the expression of $A$. calcoaceticus $\operatorname{rec} A$, a plasmid (pARA11) was constructed that is able to replicate in $A$. calcoaceticus and that contains $1.1 \mathrm{~kb}$ of DNA upstream of the $\operatorname{rec} A$ gene, but not the complete $\operatorname{rec} A$ gene. The presence of multiple copies of the $\operatorname{rec} A$ promoter might titrate a regulator from the chromosomal $\operatorname{rec} A$ promoter. A lower level of $\beta$ galactosidase produced in this situation would then point towards the presence of an activator, while a $\beta$ galactosidase level comparable to that in DNA-damaged cells would indicate that a repressor is involved. pARA11 is based on the $E$. coli- $A$. calcoaceticus shuttle vector pWH1274 (Hunger et al., 1990), which shows a stable copy number of between five and ten in $A$. calcoaceticus (data not shown). pARA11 contains $0.4 \mathrm{~kb}$ of the $5^{\prime}$-end of the $\operatorname{rec} A$ gene and $1.1 \mathrm{~kb}$ of upstream sequence. This 
(a)

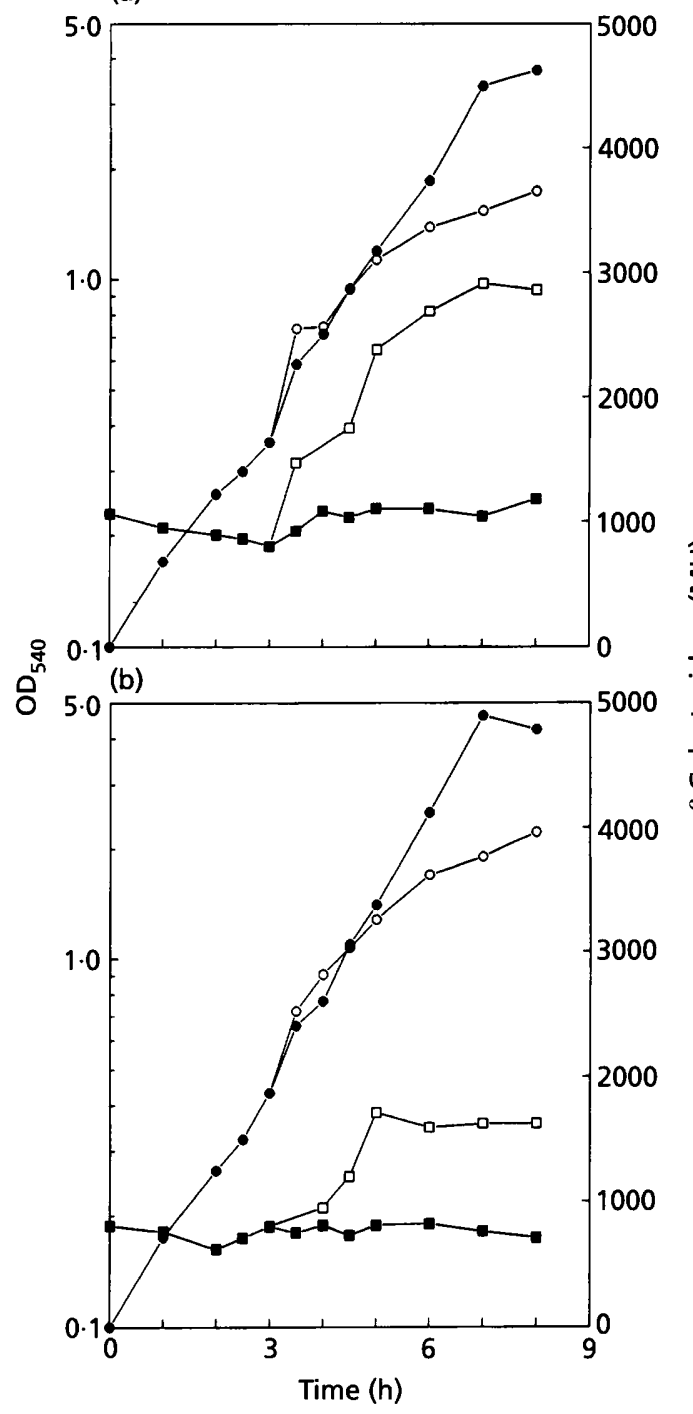

Fig. 2. Effect of mitomycin $C$ on growth and $\beta$-galactosidase activities of $A$. calcoaceticus strains AAC406 (a) and AAC407 (b). An overnight culture was diluted to an $O D_{540}$ of 0.1 into fresh minimal medium containing $15 \mu \mathrm{g}$ kanamycin $\mathrm{ml}^{-1}$. After $3 \mathrm{~h}$ incubation at $30^{\circ} \mathrm{C}$ on a rotary shaker, $4 \mu \mathrm{g}$ mitomycin $\mathrm{C} \mathrm{ml}^{-1}$ was added. Filled symbols, untreated culture; open symbols, mitomycin-C-treated culture; $0, O$, growth; $\square, \square, \beta$ galactosidase activity. The experiments were carried out three times with essentially the same results and each curve shown is based on a representative experiment. The $\beta$-galactosidase levels given are the mean of two measurements (SD approximately $10 \%$ ).

amount of upstream sequence should be sufficient to comprise all sites involved in regulation of $\operatorname{rec} A$ transcription. Both pARA11 and pWH1274 were independently introduced into strains AAC406 and AAC407 and copy numbers of both plasmids were found to be comparable (data not shown). Transformants containing the plasmids in their independently replicating forms were selected by plating transformants at an ampicillin concentration of $600 \mu \mathrm{g} \mathrm{ml}^{-1}$. Although strain AAC407 itself is already resistant to $200 \mu \mathrm{g}$ ampicillin $\mathrm{ml}^{-1}$, transformants of this strain could be isolated by selection against higher concentrations (e.g. $600 \mu \mathrm{g} \mathrm{ml}^{-1}$ ) of this antibiotic. Plasmid isolations showed the presence of independently replicating pWH1274 and pARA11 in both the AAC406 and the AAC407 transformants (data not shown).

Levels of $\beta$-galactosidase activity were measured using cultures of AAC406 and AAC407 in the middle of their exponential-phase growth $\left(\mathrm{OD}_{540}\right.$ approximately $\left.0 \cdot 4\right)$ and containing pWH1274 or pARA11. The results show that when AAC406 and AAC407 each harbour pARA11, they exhibit $\operatorname{rec} A$ transcription levels that are comparable to the levels found in DNA-damage-induced cells $(1810 \pm 130$ and $1310 \pm 90 \mathrm{MU}$, respectively; mean of two independent experiments). The control strains, harbouring $\mathrm{pWH} 1274$, showed $\beta$-galactosidase levels similar to those found in AAC406 and AAC407 without

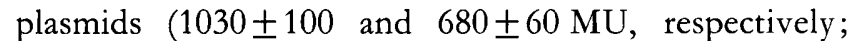
mean of two independent experiments). This indicates that a repressor, encoded by the chromosome of $A$. calcoaceticus, is titrated by the plasmid-derived copies of the $\operatorname{rec} A$ promoter, which results in a derepressed $\operatorname{rec} A:: \operatorname{lac} Z$ operon fusion.

\section{Effect of competence induction on recA transcription}

One of the typical characteristics of competence development for natural transformation in $A$. calcoaceticus BD413 is that after dilution of an overnight culture into fresh medium, competence is induced and maximal competence is reached after $1-2 \mathrm{~h}$ growth at maximal growth rate (Palmen et al., 1993). Chromosomal DNA, taken up via the natural transformation pathway, has to be incorporated into the recipient's chromosome in order to allow coding sequences to be expressed. Integration is facilitated by homologous recombination, a process in which RecA plays an important role. Therefore, it is conceivable that $\operatorname{rec} A$ expression is also under control of the competence regulatory system, as has been observed, for instance, in B. subtilis (Cheo et al., 1993). A first indication that transcription of the $A$. calcoaceticus $\operatorname{rec} A$ gene is not influenced by the level of competence for natural transformation can be derived from the observation that in batch cultures of both strain AAC406 and strain AAC407, $\beta$-galactosidase levels do not change significantly while the cells are progressing through the consecutive stages of growth (Fig. 2), while competence of $A$. calcoaceticus is low immediately after dilution of an overnight culture and is maximal after $2 \mathrm{~h}$ incubation (Palmen et al., 1993).

To determine more precisely the effect of the level of competence on the induction of $\operatorname{rec} A$ transcription, AAC407 was grown under conditions known to give a low expression of competence. To obtain a culture with a low level of competence, AAC407 was grown in a steadystate batch culture in minimal medium. It has been shown (Palmen et al., 1994) that in such a system of extended exponential growth, the transformation frequency of $A$. calcoaceticus, used as an indicator for the level of competence for natural transformation, gradually decreases 
several orders of magnitude. Extended exponential growth was obtained by repeatedly diluting an $A$. calcoaceticus AAC407 culture into fresh, prewarmed minimal medium as soon as an $\mathrm{OD}_{540}$ of $0 \cdot 1$ was reached. After $4 \mathrm{~d}$ of exponential growth, the transformation frequency and the $\beta$-galactosidase level of the culture were determined and compared to the transformation frequency and the $\beta$-galactosidase level obtained, using AAC407 at the level of maximal competence $(2 \mathrm{~h}$ after the initial 25 fold dilution into fresh, prewarmed minimal medium). While the transformation frequencies differed 1000-fold $\left(1 \times 10^{-5}\right.$ after extended exponential growth and $1 \times 10^{-2}$ at maximal competence), the $\beta$-galactosidase levels were comparable (690 MU after extended exponential growth and $630 \mathrm{MU}$ at maximal competence). This indicates that the level of competence for natural transformation of $A$. calcoaceticus has no effect on $\operatorname{rec} A$ gene transcription.

To obtain a culture with a minimal level of competence, strain AAC407 was grown in a carbon-source-limited chemostat at a dilution rate of $0 \cdot 1 \mathrm{~h}^{-1}$ (Palmen et al., 1994). The transformation frequency of such a culture in steady state was $1 \times 10^{-6}$, whereas the batch culture, run in parallel, transformed at a frequency of $1 \times 10^{-2}$ (i.e. a 10000 -fold decrease in transformability). Determination of the $\beta$-galactosidase level in four independent samples from two independent chemostat cultures, much to our surprise, showed a mean $\beta$-galactosidase activity of 1240 ( \pm 130$) \mathrm{MU}$, i.e. comparable to the level obtained upon induction of DNA damage with MMS in batch-cultured cells (see above).

The MU normalizes enzyme activity by taking into account the amount of cells via measurement of the optical density. Cells grown in a batch culture do not necessarily have the same scattering characteristics as cells grown in a carbon-source-limited chemostat. However, cells from chemostat and from batch cultures (in minimal medium) with comparable optical densities were found to display comparable protein to optical density ratios (data not shown). Thus, the $\beta$-galactosidase levels found in the chemostat culture can be readily compared to those found in batch cultures in minimal medium (Fig. 2). Accordingly, it can be concluded that the activity of $\beta$ galactosidase in chemostat cultures (minimally competent) of AAC407 is approximately twofold higher than in batch cultures (maximally competent) $[740( \pm 70) \mathrm{MU}]$. Thus, it appears that $\operatorname{rec} A$ transcription in the carbonlimited chemostat culture is induced to a similar extent as in batch cultures subject to DNA damage.

\section{DISCUSSION}

We have examined the regulation of the $A$. calcoaceticus $\operatorname{rec} A$ gene using lac $Z$ operon fusions integrated into the $A$. calcoaceticus chromosome at the position of the wildtype $\operatorname{rec} A$ gene. This situation is closest to the wild-type situation, in contrast to using operon fusions located on plasmids, where multicopy effects occur and the regulatory region incorporated into the construct might be incomplete. The use of both Campbell-like and replacement recombinants made it possible to study gene expression in the presence and absence of the functional gene product, which in the case of RecA is particularly important.

The regulation of the expression of the $A$. calcoaceticus $\operatorname{rec} A$ gene is unique: the induction of its transcription by DNA damage is independent of the presence of functional RecA. The typical SOS response of E. coli (Little \& Mount, 1982), but e.g. also of B. subtilis (Cheo et al., 1991), P. stutzeri (Vosman et al., 1993) and H. infuenzae (Zulty \& Barcak, 1993), is dependent on a functional RecA protein. In these organisms, $\operatorname{Rec} A$ is required, after activation by ssDNA, for enhancement of autocleavage activity of LexA, the repressor of the $\operatorname{rec} A$ gene (and other SOSinducible genes). In agreement with this, it was recently observed that the upstream sequence of the $A$. calcoaceticus $\operatorname{rec} A$ gene is not preceded by a LexA-binding motif (Gregg-Jolly \& Ornston, 1994). The promoter regions of the rec $A$ genes of $T$. ferrooxidans (Ramesar et al., 1989), $N$. gonorrboeae (Fyfe \& Davies, 1990) and Agrobacterium tumefaciens (Wardhan et al., 1992) have also been reported to lack discernable LexA-binding sites. However, $A$. calcoaceticus is the first organism for which it has been observed that induction of $\operatorname{rec} A$ by DNA damage is independent of functional $\operatorname{Rec} A$.

Our results suggest that a LexA-like protein probably is not involved in the regulation of $A$. calcoaceticus $\operatorname{rec} A$ expression. In an attempt to characterize the occurrence of the SOS system in Gram-negative bacteria, Fernandez de Henestrosa et al. (1991) have studied the transcription of the $E$. coli $\operatorname{rec} A$ gene in 30 different species. An E. coli $\operatorname{rec} A$ :: lac $Z$ operon fusion was transferred into these bacteria on a broad-host-range plasmid and transcription levels in the absence and presence of mitomycin $C$ were determined. It was found that in a wild-type $A$. calcoaceticus background, the $E$. coli $\operatorname{rec} A$ gene is induced twofold upon treatment with mitomycin $\mathrm{C}$, which is comparable to our results. The authors' conclusion that this indicates that $A$. calcoaceticus possesses a LexA-dependent SOS induction mechanism, comparable to the E. coli mechanism, has to be questioned on the basis of the RecAindependent induction, as we report in this study (and because of the absence of a LexA-binding motif upstream of the $\operatorname{rec} A$ gene). These results demonstrate that at least RecA-deficient mutants have to be analysed before conclusions can be drawn about the presence of an SOSlike response.

There is a limited (approximately twofold) inductive response of $A$. calcoaceticus rec $A$ upon addition of DNAdamaging agents. In contrast, $E$. coli increases $\operatorname{rec} A$ transcription 17-fold upon such a treatment (Casaregola $e t$ al., 1982). Comparably low levels of $\operatorname{rec} A$ induction by DNA damage have been observed in $A$. vinelandii (at most twofold; Venkatesh \& Das, 1992) and $H$. influenzae (approximately threefold; Zulty \& Barcak, 1993); interestingly, both are also naturally transformable Gramnegative organisms. A possible explanation for the absence of a large inductive response after addition of a DNA-damage-inducing agent may be the fact that the constitutive level of $\operatorname{rec} A$ transcription in these organisms 
is substantial. This would be in agreement with the observation that $\operatorname{rec} A$ transcription is not induced by the competence regulatory system of $H$. influenzae (Zulty \& Barcak, 1993) and $A$. calcoaceticus. Also in P. stutzeri, no indications have been obtained that competence for natural transformation influences $\operatorname{rec} A$ expression (Vosman et al., 1993; P. J. G. Rauch, unpublished results). Apparently, the constitutive level of $\operatorname{rec} A$ transcription in all these Gram-negative organisms is sufficiently high to allow integration of internalized DNA.

Definite conclusions about the regulation of the expression of $A$. calcoaceticus $\operatorname{rec} A$ in $E$. coli, which are beyond the framework of this investigation, cannot yet be drawn. The complementation of the $\operatorname{rec} A$ genotype of E. coli $\mathrm{DH} 5 \alpha$ by the RecA enzyme from Acinetobacter via pARA0 may (partly) be due to a plasmid-derived promoter. LacZ-expression levels from transcriptional fusion constructs with $A$. calcoaceticus rec $A$ were not measurably affected by MMS, neither in $E$. coli DH5 $\alpha$ nor in the $\operatorname{rec} A^{+}$ lex $A^{+}$strain $E$. coli $\mathrm{AB} 1157$. However, variations in plasmid copy number may interfere in these experiments with changes in the expression level of $\operatorname{rec} A$ : : lac $Z$.

Multiple copies of the $\operatorname{rec} A$ promoter region (introduced via $\mathrm{pARA11)}$ appear to titrate a repressor from the chromosomal $\operatorname{rec} A$ promoter. This titration effect of the $\operatorname{rec} A$ promoter is not recognizable in a comparison of AAC406 and AAC407. We interpret this latter observation, however, as a consequence of differences in mRNA stability (see below). Future experiments should be aimed at identifying the postulated repressor and at analysing how its response to DNA damage is effectuated.

In species displaying LexA-dependent SOS induction [e.g. E. coli (Casaregola et al., 1982) or $P$. aeruginosa (Horn $\&$ Ohman, 1988)], a $\operatorname{rec} A$ : : lac $Z$ fusion strain has a lower level of transcription than a Campbell-like integrant containing an additional wild-type copy of $\operatorname{rec} A$. This can be explained by a titration effect of $\operatorname{rec} A$ regulatory sequences on the LexA repressor, resulting in partial derepression of the $\operatorname{rec} A$ promoter. This is not the case in $A$. calcoaceticus. The $\beta$-galactosidase activity of strain AAC407, under non-inducing conditions, is approximately $75 \%$ of the level found in strain AAC406. If this difference in uninduced transcription levels would be the result of a difference in the basal levels of $\operatorname{rec} A$ expression, the induced levels of transcription would be expected to be similar. However, the mitomycin $\mathrm{C}$ - and the PARA11induced $\beta$-galactosidase levels that are reached in AAC407 are also lower than those in AAC406 (mitomycin C: $60 \%$; pARA11: $73 \%$ ). We favour the explanation that the differences in $\beta$-galactosidase levels measured between these two strains do not reflect a difference in transcription level, but a difference in stability of the $\mathrm{mRNAs}$ produced in both strains. Since in strain AAC406 the sequences downstream of the $\operatorname{rec} A$ gene are identical to the wildtype sequences (Fig. 1), synthesis of the $\operatorname{rec} A:$ :lac $Z$ mRNA is expected to terminate at the wild-type site. It is conceivable that this termination site is located downstream from the HindIII site, used in the cloning of the $\operatorname{rec} A$ gene in pARA4. If this is the case, termination of transcription of the $\operatorname{rec} A$ : : lac $Z$ fusion in strain AAC407 probably occurs somewhere in the vector sequence present downstream of the $\operatorname{rec} A$ : : lac $Z$ fusion in AAC407 (Fig. 1). This could lead to an mRNA that is less stable than the mRNA synthesized in strain AAC406. The differences in $\beta$-galactosidase levels, measured in strains AAC406 and AAC407, however, do not discount our conclusion that transcription of the $\operatorname{rec} A$ gene in $A$. calcoaceticus is induced two- to threefold in cells that have been treated with DNA-damage-inducing agents, by a mechanism that is independent of the presence of functional RecA, and that competence development in $A$. calcoaceticus does not lead to increased $\operatorname{rec} A$ expression.

The results obtained with the carbon-limited chemostat culture confirm the conclusion drawn from the steadystate batch culture, i.e. a less than maximal level of competence for natural transformation does not lead to decreasing levels of $\operatorname{rec} A$ expression. In addition, however, the chemostat experiment shows the surprising result that carbon limitation, at a relatively low growth rate, gives rise to an increase of $\operatorname{rec} A$ expression. The regulatory mechanism(s) responsible for this increase is/are still completely unknown. However, as the level of RecA in the cell is an important factor in determining the frequency at which spontaneous mutations occur (GreggJolly \& Ornston, 1994), this is one mechanism by which this mutation rate is coupled to the physiological state of the cells (see also Mittler \& Lenski, 1990).

\section{REFERENCES}

Bagdasarian, M., Lurz, R., Rückert, B., Franklin, F. C. H., Bagdasarian, M. M., Frey, J. \& Timmis, K. N. (1981). Specificpurpose plasmid cloning vectors. II. Broad host range, high copy number, RSF1010-derived vectors, and a host-vector system for gene cloning in Pseudomonas. Gene 16, 237-247.

Bradford, M. M. (1976). A rapid and sensitive method for quantitation of microgram quantities of protein utilizing the principle of protein-dye binding. Anal Biochem 72, 248-254.

Casaregola, S., D'Ari, R. \& Huisman, O. (1982). Quantitative evaluation of $\operatorname{rec} A$ gene expression in Escherichia coli. Mol $\&$ Gen Genet 185, 430-439.

Cheo, D. L., Bayles, K. W. \& Yasbin, R. E. (1991). Cloning and characterization of DNA damage-inducible promoter regions from Bacillus subtilis. J Bacteriol 173, 1696-1703.

Cheo, D. L., Bayles, K. W. \& Yasbin, R. E. (1993). Elucidation of regulatory elements that control damage induction and competence induction of the Bacillus subtilis SOS system. $J$ Bacteriol 175, 5907-5915.

Cox, M. M. (1991). The RecA protein as a recombinational repair system. Mol Microbiol 5, 1295-1299.

De Vos, W. M. \& Venema, G. (1982). Transformation of Bacillus subtilis competent cells: identification of a protein involved in recombination. Mol \& Gen Genet 187, 439-445.

Dybvig, K., Hollingshead, S. K., Heath, D. G., Clewell, D. B., Sun, F. \& Woodward, A. (1992). Degenerate oligonucleotide primers for enzymatic amplification of $\operatorname{rec} A$ sequences from gram-positive bacteria and Mycoplasmas. J Bacteriol 174, 2729-2732.

Fernandez de Henestrosa, A., Calero, A. R. \& Barbé, J. (1991). Expression of the $\operatorname{rec} A$ gene of Escherichia coli in several species of gram-negative bacteria. Mol $\mathcal{E}$ Gen Genet 226, 503-506. 
Fyfe, J. A. \& Davies, J. K. (1990). Nucleotide sequence and expression in Escherichia coli of the $\operatorname{rec} A$ gene of Neisseria gonorriboeae. Gene 93, 151-156.

Gregg-Jolly, L. A. \& Ornston, L. N. (1994). Properties of Acinetobacter calcoaceticus $\operatorname{rec} A$ and its contribution to intracellular gene conversion. Mol Microbiol 12, 985-992.

Guerry, P., Pope, P. M., Burr, D. H., Leifer, J., Joseph, S. W. \& Bourgeois, A. L. (1994). Development and characterization of $\operatorname{rec} A$ mutants of Campylobacter jejuni for inclusion in attenuated vaccines. Infect Immun 62, 426-432.

Hanahan, D. (1983). Studies on transformation of Escherichia coli with plasmids. J Mol Biol 166, 557-580.

Higashitani, N., Higashitani, A., Roth, A. \& Horiuchi, K. (1992). SOS induction in Eschericbia coli by infection with mutant filamentous phage that are defective in initiation of complementarystrand DNA synthesis. J Bacteriol 174, 1612-1618.

Horn, J. M. \& Ohman, D. E. (1988). Autogenous regulation and kinetics of induction of Pseudomonas aeruginosa $\operatorname{rec} A$ transcription as analyzed with operon fusions. $J$ Bacteriol 170, 4699-4705.

Hunger, M., Schmucker, R., Kishan, V. \& Hillen, W. (1990). Analysis and nucleotide sequence of an origin of DNA replication in Acinetobacter calcoaceticus and its use for Escherichia coli shuttle plasmids. Gene 87, 45-51.

Juni, E. (1972). Interspecies transformation of Acinetobacter: genetic evidence for a ubiquitous genus. J Bacteriol 112, 917-931.

Juni, E. (1974). Simple genetic transformation assay for rapid diagnosis of Moraxella osloensis. Appl Microbiol 27, 16-24.

Kok, R. G., Christoffels, V. M., Vosman, B. \& Hellingwerf, K. J. (1993). Growth-phase-dependent expression of the lipolytic system of Acinetobacter calcoaceticus BD413: cloning of a gene encoding one of the esterases. J Gen Microbiol 139, 2329-2342.

Little, J. W. \& Mount, D. W. (1982). The SOS regulatory system of E. coli. Cell 29, 11-22.

Lovett, C. M., Love, P. E., Yasbin, R. E. \& Roberts, J. W. (1988). SOS-like induction in Bacillus subtilis: induction of the RecA protein analog and a damage-inducible operon by DNA damage in $\mathrm{Rec}^{+}$and DNA repair-deficient strains. J Bacteriol 170, 1467-1474.

Martin, B., Ruellan, J. M., Angelo, J. F., Deverot, R. \& Claverys, J. P. (1992). Identification of the $\operatorname{rec} A$ gene of $S$ treptococcus pneumoniae. Nucleic Acids Res 20, 6412.

Martin, B., García, P., Castanié, M.-P. \& Claverys, J. P. (1995). The $\operatorname{rec} A$ gene of Streptococcus pneumoniae is part of a competenceinduced operon and controls lysogenic induction. Mol Microbiol 15, 367-379.

Masters, C. I., Smith, M. D., Gutman, P. D. \& Minton, K. W. (1991). Heterozygosity and instability of amplified chromosomal insertions in the radioresistant bacterium Deinococcus radiodurans. J Bacteriol 173, 6110-6117.

Miller, J. H. (1982). Experiments in Molecular Genetics. Cold Spring Harbor, NY: Cold Spring Harbor Laboratory.

Miller, R. V. \& Kokjohn, T. A. (1990). General microbiology of $\operatorname{rec} A$ : environmental and evolutionary significance. Annu Rev Microbiol 44, 365-394.

Mittler, J. E. \& Lenski, R. E. (1990). New data on excisions of Mu from E. coli MCS2 cast doubt on directed mutation hypothesis. Nature 344, 173-175.

Nilsson, B., Uhlén, M., Josephson, S., Gatenbeck, S. \& Philipson, L. (1983). An improved positive selection plasmid vector con- structed by oligonucleotide mediated mutagenesis. Nucleic Acids Res 11, 8019-8029.

Palmen, R., Vosman, B., Kok, R., van der Zee, J. R. \& Hellingwerf, K. J. (1992). Characterization of transformation-deficient mutants of Acinetobacter calcoaceticus. Mol Microbiol 6, 1747-1754.

Palmen, R., Vosman, B., Buijsman, P., Breek, K. \& Hellingwerf, K. J. (1993). Physiological characterization of natural transformation in Acinetobacter calcoaceticus. J Gen Microbiol 139, 295-305.

Palmen, R., Buijsman, P. \& Hellingwerf, K. J. (1994). Physiological regulation of competence induction for natural transformation in Acinetobacter calcoaceticus. Arch Microbiol 162, 344-351.

Pearce, B. J., Naughton, A. M., Campbell, E. A. \& Masure, H. R. (1995). The rec locus, a competence-induced operon in Streptococcus pneumoniae. J Bacteriol 177, 86-93.

Raina, J. L. \& Macrina, F. L. (1982). A competence specific inducible protein promotes in vivo recombination in Streptococcus sanguis. Mol \& Gen Genet 185, 21-29.

Ramesar, R. S., Abratt, V., Woods, D. R. \& Rawlings, D. E. (1989). Nucleotide sequence and expression of a cloned Thiobacillus ferrooxidans rec $A$ gene in Eschericbia coli. Gene 78, 1-8.

Raymond-Denise, A. \& Guillen, N. (1992). Expression of the Bacillus subtilis dinR and $\operatorname{rec} A$ genes after DNA damage and during competence. $J$ Bacteriol 174, 3171-3176.

Sambrook, J., Fritsch, E. F. \& Maniatis, T. (1989). Molecular Cloning: a Laboratory Manual, 2nd edn. Cold Spring Harbor, NY: Cold Spring Harbor Laboratory.

Story, R. M., Bishop, D. K., Kleckner, N. \& Steitz, T. A. (1993). Structural relationship of bacterial RecA proteins to recombination proteins from bacteriophage T4 and yeast. Science 259, 1892-1896.

Stranathan, M. C., Bayles, K. W. \& Yasbin, R. E. (1990). The nucleotide sequence of the rec $E^{+}$gene of Bacillus subtilis. Nucleic Acids Res 18, 4249.

Venkatesh, T. V. \& Das, H. K. (1992). The Azotobacter vinelandii $\operatorname{rec} A$ gene: sequence analysis and regulation of expression. Gene 113, 4753.

Vieira, J. \& Messing, J. (1982). The pUC plasmids, an M13mp7derived system for insertion mutagenesis and sequencing with synthetic universal primers. Gene 19, 259-268.

Vosman, B. \& Hellingwerf, K. J. (1991). Molecular cloning and functional characterization of a $\operatorname{rec} A$ analog from Pseudomonas stutzeri and construction of a $P$. stutzeri rec $A$ mutant. Antonie Leeuwenboek 59, 115-123.

Vosman, B., Rauch, P. J. G., Westerhoff, H. V. \& Hellingwerf, K. J. (1993). Regulation of the expression of the Pseudomonas stutzeri rec $A$ gene. Antonie Leeuvenboek 63, 55-62.

Wardhan, H., McPherson, M. J., Harris, C. A., Sharma, E. \& Sastry, G. R. K. (1992). Molecular analysis of the rec $A$ gene of Agrobacterium tumefaciens C58. Gene 121, 133-136.

Wise, E. M., Alexander, S. P. \& Powers, M. (1973). Adenosine $3^{\prime}: 5^{\prime}$-cyclic monophosphate as a regulator of bacterial transformation. Proc Natl Acad Sci US A 70, 471-474.

Zulty, J. J. \& Barcak, G. J. (1993). Structural organization, nucleotide sequence, and regulation of the Haemophilus influenzae rec- $1^{+}$ gene. J Bacteriol 175, 7269-7281.

Received 7 July 1995; revised 9 October 1995; accepted 29 November 1995. 